\title{
The Protective Role of Septilin Against Gamma Radiation-Induced Testicular Toxicity in Rats
}

\author{
Omaima Soliman Eissa* and Nehal Aly Moustafa** \\ *National Center for Radiation Research and Technology, Atomic Energy Authority: \\ ** Faculty of Science, Al-Azhar University, Cairo, Egypt
}

\begin{abstract}
Backgrounds: This study deals with evaluation of the histological and some histochemical alterations in rat testes induced by whole body gamma irradiation as well as evaluation of the protective effect of septilin (a herbal preparation) against these effects.

Results : The obtained results indicated that doses of ( $3 \mathrm{~Gy}$ and $6 \mathrm{~Gy}$ ) gamma radiation have testicular toxic effects in rats. The histological lesions observed in the testes varied between vacuolation, swelling, pyknosis and even necrosis in some spermatogenic cells as well as significant depletion in the number of spermatogonia, primary spermatocytes, secondary spermatocytes and spermatids. The histochemical observations revealed diminution in the polysaccharides content and increase in the collagen fibres in the testis of irradiated animals. These effects were mostly perceptive with the high dose of the radiation than with the lower one. Treatment with septilin (a herbal preparation) for one week followed by gamma radiation proved that septilin has a protective effect against gamma radiation-induced toxic effects in the testes of rats; where most of the histological and histochemical changes observed due to irradiation were minimized to a large extent; however there was no complete protection.

Conclusion: Thus, this study concluded that gamma-irradiation exerts toxic effects in the testes of rats and pre-treatment with septilin inhibits these toxic effects, which in turn advocate using such herbal extract as a radioprotector.
\end{abstract}

Key words: Septilin, $\gamma$-radiation, Histology, Testis, Rats.

\section{Introduction}

Radiation can change the characteristics of the cell nucleus and cytoplasm, as mammalian germ cells are very sensitive to ionizing radiation (Dobson and Felton, 1983). Ionized radiation, being one of the environmental cytotoxic factors, causes death of the germinal cells and therefore, sterility (Meistrich, 1993 and Georgieva et al., 2005).

The testis is a main target organ of radiation damage; it has been reported that irradiation induces several histopathological consequences in the organs and tissues, including the increase of loose fibrous tissue (Matalka et al., 1994 and Yang et al., 2000). Moreover, ionizing radiation of normal tissue results in fibrosis, which is perhaps the most effect of radiation (Geraci et al., 1992), in the testis, resulting in depletion of more advanced spermatogenic cells (Kangasniemi et al., 1990). The differentiating spermatogonia are very sensitive to radiation and are killed under the effect of doses less than $3 \mathrm{~Gy}$ in the Sprague-Dawley rat (Kangasniemi et al., 1990), in humans (Rowley et al., 1974), and in mice (Mian et al., 1977).

The radioprotective agents are compounds that are administered before exposure to ionizing radiation to reduce its damaging effects, including radiationinduced lethality (Satoh et al., 2003). The discovery of radioprotectors for the first time seemed to be very promising (in radiotherapy) and has attracted the interest of a number of radiobiologists. Although synthetic radioprotectors such as the aminothiols have yielded the highest protective factors; typically they are more toxic (Rades et al., 2004) than naturally occurring protectors (Weiss and Landauer, 2003). Thereafter different plant extracts were tested against radiation effects and showed potential radioprotective activities 
in mammals (Uma Devi et al., 2000; Lamartiniere et al., 2002; Jagetia et al., 2004 and Landauer et al., 2005). The effect of various doses $(5,10,20,40,60,80,100$, 120,140 and $160 \mathrm{mg} / \mathrm{kg} \mathrm{b}$. wt.) of $50 \%$ ethanolic extract of Septilin (a herbal preparation) on the radiation-induced mortality was studied in mice exposed to 10 Gy of gamma-irradiation daily. Treatment of mice with different doses of septilin, for 5 days before irradiation, delayed the onset of mortality and reduced the symptoms of radiation sickness when compared with the drug untreated irradiated controls (Jagetia and Baliga, 2004). The present work aimed to investigate whether septilin pretreatment could prevent gamma radiation-induced histological damage in the testes of rats.

\section{Material And Methods}

The experimental animals in the present investigation were 40 male albino rats (Rattus norvegicus) with average body weights 100-130 g., obtained from the Egyptian Organization for Vaccine and Biological Preparations at Helwan. Animals allowed a period of two weeks preexperimentation to be adapted to the laboratory conditions. Food and water were supplied daily ad libitum. Animals were divided into four main groups; the first one (10 rats) sited as control. The second group (6 rats) was treated with septilin in a daily oral dose $(100 \mathrm{mg} / \mathrm{kg} \mathrm{b}$. wt.) for one week (positive control). The third group (12 rats) was divided into two equal subgroups; the first one was subjected to whole body $\gamma$ irradiation at a sub-lethal single dose of 3Gy and the second one subjected to whole body $\gamma$-irradiation at a sub-lethal single dose of 6Gy. The fourth main group (12 animals) received septilin in a daily oral dose of $100 \mathrm{mg} / \mathrm{kg} \mathrm{b}$. wt. for one week, and then divided into two equal subgroups; the first one subjected to whole body $\gamma$ irradiation at a sub-lethal single dose of 3Gy and the second one was subjected to whole body $\gamma$-irradiation at a sub-lethal single dose level of 6Gy. All the groups were sacrificed after one week post irradiation.
Whole body $\gamma$-irradiation was performed using Cesium 137 Biological $\gamma$ cell-40 irradiation facility belonging to The National Center for Radiation Research and Technology (NCRRT). The dose rate was 1 $\mathrm{Gy} / 1.42 \mathrm{~min}$ at the time of the experiment.

The herb used in the present investigation was septilin Himalaya (a product of heral healthcare), Drug Co. Private Ltd; it is an Ayurvedic herbal preparation containing various herbs and minerals. Its main ingredients are (in $\mathrm{mg}$ ): Balsamodendron mukul 162; Sank Bhasma 32: Maharasnadi qoath, 65; Tinospora cordifolia, 49; Rubia cordifolia, 32; Emblica officinalis, 16; Moringa pterigosperma, 16: Glycyrrhiza glabra, 6. It has been reported to have anti-bacterial, antiinflammatory, anti-exudative and immunostimulatory effect (Rom, 1984; Kumar et $a$ l., 1993 and Sharma and Ray, 1997). The dose used in this study was $100 \mathrm{mg} / \mathrm{kg} \mathrm{b}$. wt./day as oral administration using a stomach tube for 7 days (Jagetia and Baliga, 2004).

The testes of control and treated animals were excised, washed with normal saline and fixed in Bouin's solution for 24 to 48 hours. They were dehydrated in graded ethanol series, embedded in paraplast, cut in sections at a thickness of 6un, stained with Harris haematoxylin and eosin. Masson's trichrome stain was applied for demonstration of collagen fibres (Pearse, 1972). PAS stain was used for demonstration of the polysaccharides (Mc Manus, 1946).

Statistical significancy among the groups was performed using Student's $t$ test.

\section{Results}

\section{The control group:}

The parenchyma of the testis of albino rat, Rattus norvegicus is composed of many seminiferous tubules of varying sizes; each is surrounded by an outer thin layer of connective tissue and lined with spermatogenic epithelium that surrounds a central lumen. The epithelium consists of Sertoli cells and spermatogenic cells. The 
interstitial cells are found mostly in groups between the seminiferous tubules; they are large and ovoid with rounded nuclei (Fig. 1). The normal structures of Sertoli cells, spermatogenic cells and spermatozoa are depicted in figure (2). Table (1) and histogram (1) show the mean count of the spermatogenic series in the control and treated groups. Figure (3) displays the collagen fibres in the testes of the control animals. The average of the polysaccharides content of the testes of the control animals (Fig. 15), indicated by PAS stain, recorded 148.61 (Table 2 and Histogram 2).

\section{Septilin- treated group:}

Investigated testes sections obtained from rats treated with septilin at a daily oral dose of $100 \mathrm{mg} / \mathrm{kg} \mathrm{b}$. wt. exhibited closely similar structure to those of the control animals denoting that septilin has no cytotoxic effects on the testes of rats. Nonsignificant increases in the numbers of the spermatogonia, primary spermatocytes, secondary spermatocytes and spermatids were recorded (Table 1). The amount of the collagen fibres in the testis recorded insignificant reduction in comparison with control. The average of the polysaccharides content of the testis in this group recorded insignificant increase in comparison with control (Table 2).

\section{Effect of $\gamma$-irradiation:}

Different histopathological lesions were noticed in the testes of rats one week post exposure to a single dose ( $3 \mathrm{~Gy}$ ) of gamma irradiation. The seminiferous tubules were mostly atrophied and the interstitial connective was widened with less number of interstitial cells (Fig. 4). The spermatogenic cells were irregularly distributed within the seminiferous tubules and the basement membrane of the tubules was abnormal. Moreover, clumped chromatin in the nuclei and vacuolated cytoplasm were encountered in most of the spermatogenic cells; some cells appeared necrotic and tissue infiltration with macrophages was perceptive (Fig. 5). In addition, depletion in spermatozoa, presence of giant cells, congestion in the blood vessels and haemorrhage in the interstitial tissue were noticed. The present data showed significant reduction in the number of spermatogonia, primary spermatocytes, secondary spermatocytes and spermatids as a resuts of exposure to $3 \mathrm{~Gy}$ gamma irradiation (Table 1). Significant increase in the collagen fibres in the testes of rats irradiated with $3 \mathrm{~Gy}$ was noticed (Fig. 8); the percentage of increment recorded $17.42 \%$. Significant reduction in the polysaccharides content was recorded as compared with the control animals; the percentage of reduction was $12.58 \%$ (Fig. 16 and Table 2).

Severe histological changes were observed in the testes of rats one week post exposure to a single dose (6Gy) of gamma radiation. Atrophy and obliterated lumen with absence of spermatozoa in the seminiferous tubules, increase of the interstitial connective tissue and depletion in the interstitial cells (Leyding cells) were the most prominent features in the testes (Fig. 6). Also, degenerated spermatogenic cells, shredding in the basement membrane that detached from the overlying cells, depletion in the spermatogonia and prevailing necrosis were ratified in the testicular tissue (Fig. 7). Significant reduction in the number of spermatogonia, primary spermatocytes, secondary spermatocytes and spermatids were found as results of exposure to 6Gy gamma irradiation, the percentages of these reduction were $68.25 \%, 68.87 \%, 81.31 \%$ and $88.43 \%$, respectively (Table 1). Obvious significant increase in the collagen fibres in the testes of rats irradiated with 6Gy was recorded and reached $38.68 \%$ (Fig. 9). Significant reduction in the polysaccharides content was recorded as compared with control animals; the percentage of reduction was $25.77 \%$ (Fig. 17 and Table 2).

\section{Septilin plus $\gamma$-irradiation:}

Obvious ameliorative effect was detected in the testes of 3 Gy gammairradiated rats treated with septilin one week prior to exposure. Most of the histopathological lesions observed in the testes of irradiated rats were disappeared and the seminiferous tubules (Fig.10) had a feature 
approximately similar to those of the control. The spermatogenic cells appeared regularly arranged within the tubules, normal tubular lumen contained spermatozoa was greatly encountered and the basement membrane of the seminiferous tubules was mostly normal. Otherwise, the interstitial connective tissue was still increased and exhibited vanish in the interstitial cells. Also, few of the seminiferous tubules showed some histopathological changes that included pyknotic and necrotic cells in the spermatogenic series (Fig. 11). The number of the cells in the spermatogenic series exhibited a high increase when compared with those of irradiated rats but showed insignificant decrease as compared with the control group (Table 1). The amount of the collagen fibres decreased as compared with those of the irradiated rats while it was still more than the control by $13.44 \%$. The average of the polysaccharides content showed large amelioration as compared with those of irradiated animals, but still decreased than the control by $9.48 \%$ (Table 2).

Slight ameliorations were noticed in the testes of 6 Gy gamma-irradiated rats treated with septilin daily for one week prior to exposure. The ameliorative effects were represented by the normal appearance of the seminiferous tubules, normal arrangement of the spermatogenic cells, and presence of spermatozoa within the lumen of some tubules (Fig. 12). Whereas the spermatogenic cells also showed different histological alterations manifested by pyknotic nuclei, necrotic cells and vacuolated cytoplasm (Fig. 13). In addition, the interstitial connective tissue was still abnormally increased and contained less number of the interstitial cells. The number of the cells in the spermatogenic series exhibited large increase when compared with those of irradiated rats and showed significant decrease as compared with the control group (Table 1). The amount of the collagen fibres decreased as compared to those of the irradiated rat while they recorded significant increase when compared with the control (Fig. 14 and Table 2). The average of the polysaccharides content showed increase as compared to those of irradiated animals while it was still less than that of the control group by $15.41 \%$ (Fig. 18 and Table 2).

Table (1): Statistical analysis of the mean counted cells of spermatogenic series in the control and treated groups.

\begin{tabular}{|c|c|c|c|c|c|c|c|}
\hline & & \multirow{2}{*}{ Control } & \multirow{2}{*}{ Septilin } & \multicolumn{2}{|c|}{ Gamma radiation } & \multicolumn{2}{|c|}{ Septilin $+\gamma-$ radiation } \\
\hline & & & & $3 \mathrm{~Gy}$ & $6 \mathrm{~Gy}$ & $3 \mathrm{~Gy}$ & $6 \mathrm{~Gy}$ \\
\hline \multirow{4}{*}{$\begin{array}{l}\text { Spermatogonia } \\
\text { (Sp) }\end{array}$} & Mean & 113.40 & 120.60 & 76.05 & 36.00 & 103.14 & 72.80 \\
\hline & \pm SD. & 14.05 & 21.78 & 14.75 & 7.62 & 19.86 & 19.88 \\
\hline & $t$-test & & 0.18 & $0.00 *$ & $0.00 *$ & 0.11 & $0.01 *$ \\
\hline & \% of change & & 6.35 & -32.94 & -68.25 & -9.05 & -35.80 \\
\hline \multirow{4}{*}{$\begin{array}{c}\text { Primary } \\
\text { Spermatocytes } \\
\text { (SP1) }\end{array}$} & Mean & 111.80 & 114.80 & 84.40 & 34.80 & 102.00 & 79.60 \\
\hline & \pm SD. & 21.66 & 26.00 & 20.85 & 12.07 & 19.46 & 20.59 \\
\hline & $t$-test & & 0.39 & $0.02 *$ & $0.00 *$ & 0.11 & $0.01 *$ \\
\hline & \% of change & & 2.68 & -24.51 & -68.87 & -8.77 & -28.80 \\
\hline \multirow{4}{*}{$\begin{array}{c}\text { Secondary } \\
\text { Spermatocytes } \\
(\text { (Sp2) }\end{array}$} & Mean & 195.80 & 198.80 & 122.60 & 36.60 & 181.20 & 119.80 \\
\hline & \pm SD. & 19.41 & 24.74 & 43.76 & 14.22 & 26.25 & 28.04 \\
\hline & $t$-test & & 0.397 & $0.02 *$ & $0.00 *$ & 0.14 & $0.00 *$ \\
\hline & $\%$ of change & & 1.53 & -37.39 & -81.31 & -7.46 & -38.82 \\
\hline \multirow{4}{*}{ Spermatids } & Mean & 212.60 & 216.60 & 136.80 & 24.60 & 184.20 & 112.40 \\
\hline & \pm SD. & 18.99 & 27.19 & 40.31 & 12.28 & 37.90 & 30.66 \\
\hline & $t$-test & & 0.34 & $0.00^{*}$ & $0.00 *$ & 0.054 & $0.00 *$ \\
\hline & \% of change & & 1.88 & -35.65 & -88.43 & -13.36 & -47.13 \\
\hline
\end{tabular}




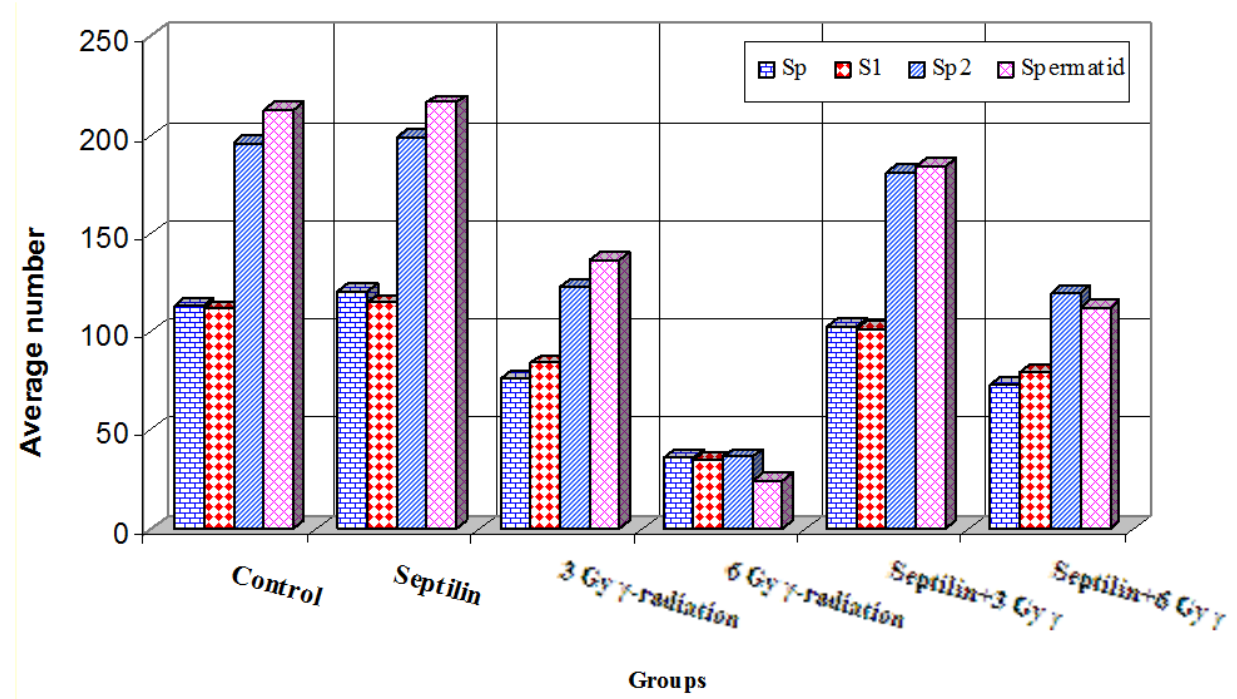

Histogram (1): Mean cells count of spermatogenic cells in the control and treated groups.

Table (2): Quantitative measurements of colour density (Pixel) of polysaccharides and collagen fibres.

\begin{tabular}{|c|c|c|c|c|c|c|c|}
\hline & & \multirow[b]{2}{*}{ Control } & \multirow[b]{2}{*}{ Septilin } & \multicolumn{2}{|c|}{$\gamma$ radiation } & \multicolumn{2}{|c|}{ Septilin $+\gamma$ radiation } \\
\hline & & & & $\begin{array}{c}\mathbf{3 G y} \gamma- \\
\text { radiation }\end{array}$ & $\begin{array}{l}\mathbf{6} \mathbf{G y} \gamma- \\
\text { radiation }\end{array}$ & $\begin{array}{c}\text { Septilin+3 } \\
\text { Gy } \gamma \text { - } \\
\text { radiation }\end{array}$ & $\begin{array}{c}\text { Septilin+6 } \\
\text { Gy } \gamma \text { - } \\
\text { radiation }\end{array}$ \\
\hline \multirow{4}{*}{ 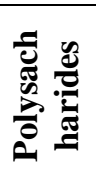 } & Average & 148.61 & 150.17 & 129.94 & 110.35 & 134.51 & 125.7 \\
\hline & SD & 16.94 & 16.19 & 14.03 & 20.79 & 13.66 & 19.02 \\
\hline & t-test & & 0.305 & $0.006^{*}$ & $0.000 *$ & $0.023^{*}$ & $0.014 *$ \\
\hline & $\%$ of change & & 1.01 & -12.58 & -25.77 & -9.48 & -15.41 \\
\hline \multirow{4}{*}{ 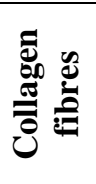 } & Average & 72.92 & 69.37 & 85.61 & 101.15 & 82.73 & 87.33 \\
\hline & SD & 8.76 & 11.48 & 12.53 & 22.48 & 11.09 & 20.25 \\
\hline & t-test & & 0.09 & $0.00 *$ & $0.00 *$ & $0.02 *$ & $0.03 *$ \\
\hline & $\%$ of change & & -4.93 & 17.42 & 38.68 & 13.44 & 19.75 \\
\hline
\end{tabular}

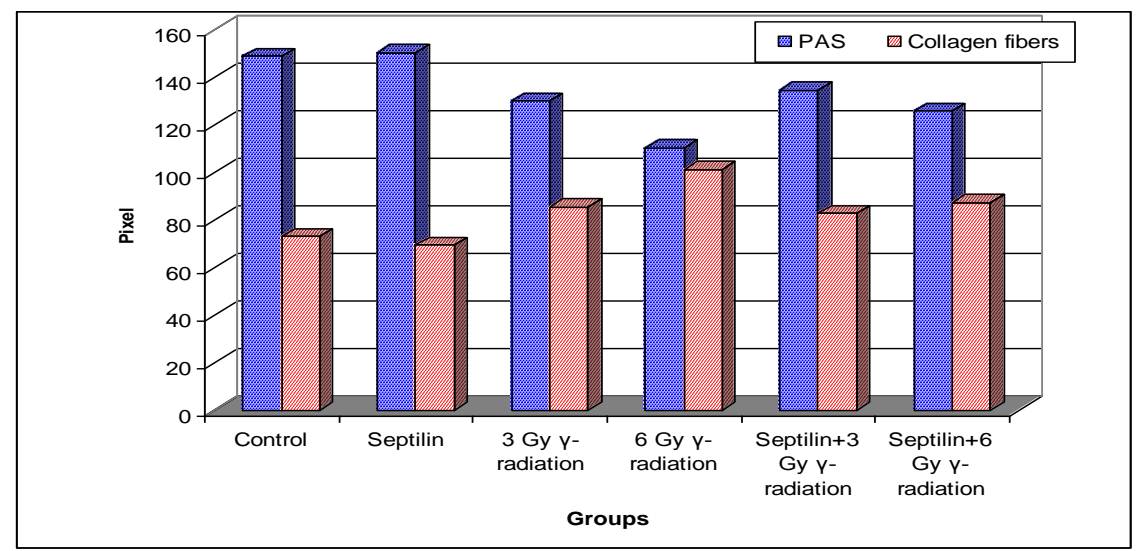

Histogram (2): Quantitative measurements of colour density (Pixel) of polysaccharides (PAS stain) and collagen fibres (Masson's trichrom stain) in the control and treated groups. 


\section{Omaima Soliman Eissa \& Nehal Aly Moustafa}
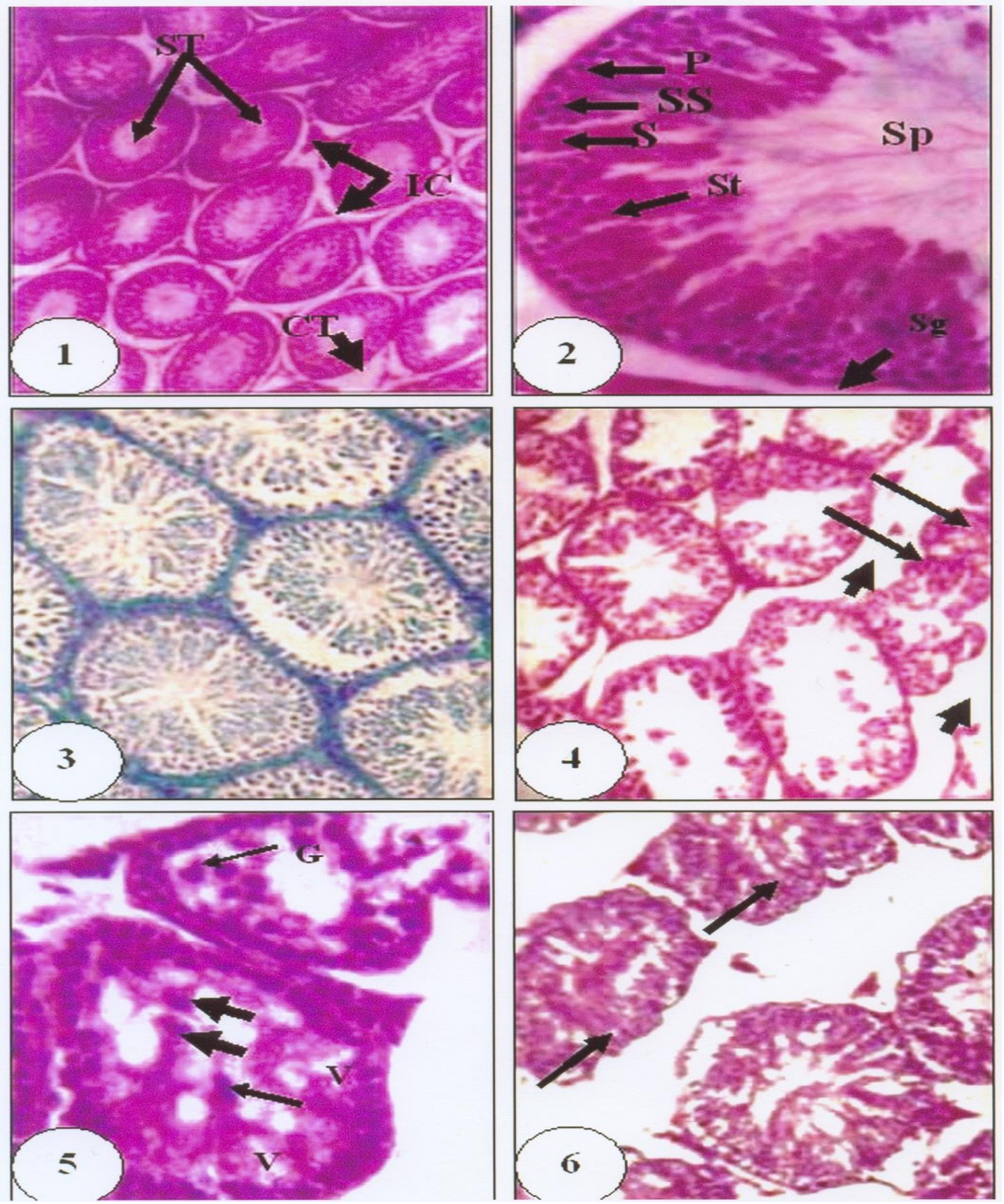

Fig. (1): Transverse section of control rat testis showing seminiferous tubules (ST), interstitial cells (IC) and inters-tubular connective tissue (CT). (H/E stain X 400).

Fig. (2): Transverse section of control rat testis showing normal structure of seminiferous tubule: spermatogonia (Sg); primary spermatocytes (P); secondary spermatocytes (SS); spermatids (St) and spermatozoa (Sp). (H/E stain X 400).

Fig. (3): Transverse section of control rat testis. (Masson's trichrome X 400).

Fig. (4): Transverse section of the testis of rat irradiated with $3 \mathrm{~Gy}$ showing atrophied seminiferous tubules (long arrows) and increase in the interstitial connective tissue (short arrows). (H/E stain X 100).

Fig. (5): Transverse section of the testis of rat irradiated with 3 Gy showing necrotic cells (thin arrow), macrophages (thick arrows) and giant cells (G). (H/E stain X 400).

Fig. (6): Transverse section of the testis of rat irradiated with 6 Gy showing atrophy and impaired lumen in the seminiferous tubules (arrows). (H/E stain X 100). 

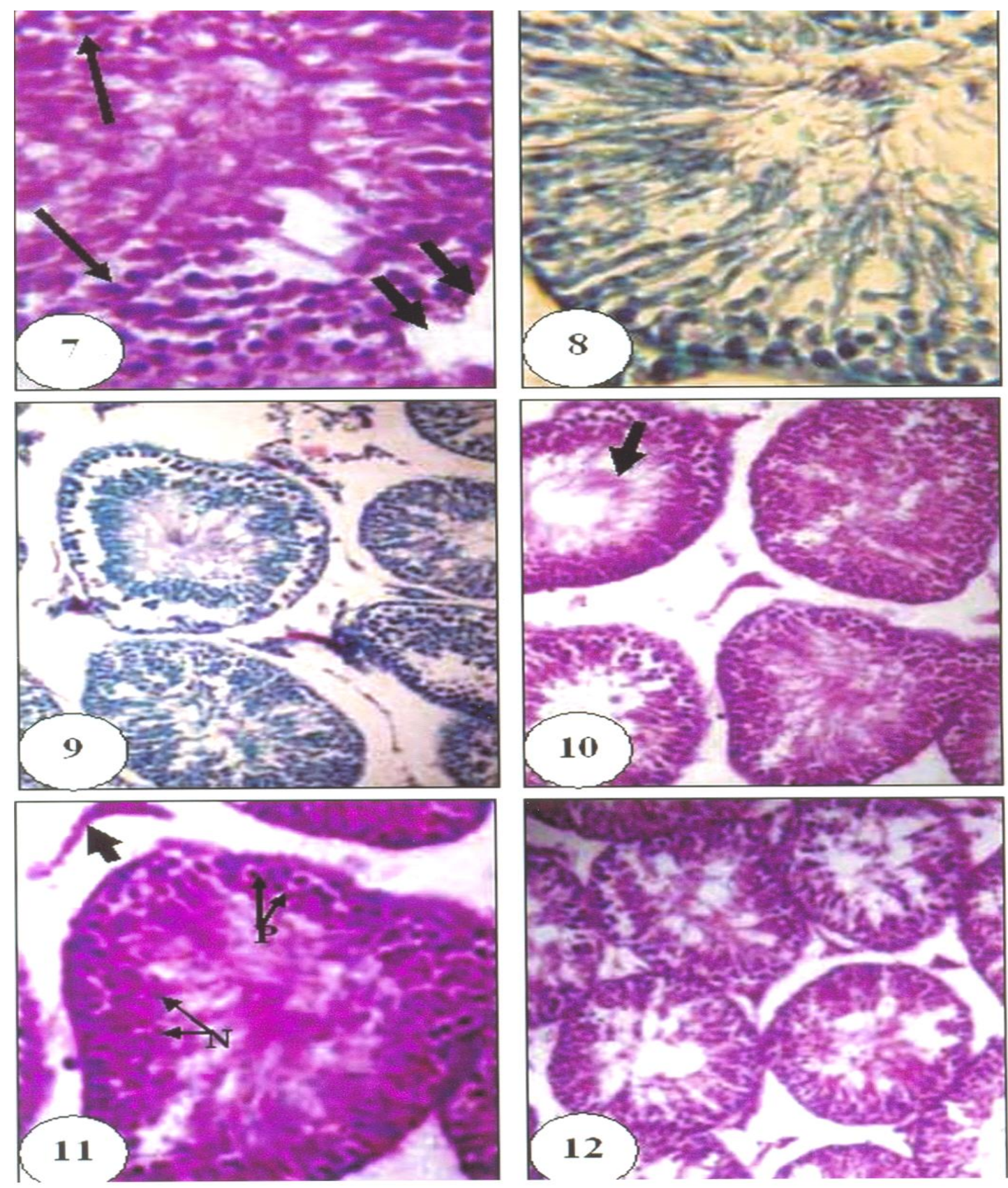

Fig. (7): Transverse section of the testis of rat irradiated with 6 Gy showing shredding in the basement membrane (short arrows) and necrotic cells (long arrows). (H/E stain X 400).

Fig. (8): Transverse section of rat irradiated with 3 Gy showing increase in the collagen fibres. (Masson's trichrome X 400).

Fig. (9): Transverse section of rat irradiated with 6 Gy showing increase in the collagen fibers. (Masson's trichrome X 100).

Fig. (10): Transverse section of the testis of rat treated with septilin and irradiated with $3 \mathrm{~Gy}$ showing normal seminiferous tubules with lumen containing spermatozoa (arrow). (H/E stain X 100).

Fig. (11): Transverse section of the testis of rat treated with septilin and irradiated with 3 Gy showing pyknotic nuclei $(\mathrm{P})$ and necrotic cells $(\mathrm{N})$. (H/E stain X 400).

Fig. (12): Transverse section of the testis of rat treated with septilin and irradiated with $6 \mathrm{~Gy}$ showing normal arrangement of the spermatogenic series. (H/E stain X 100). 

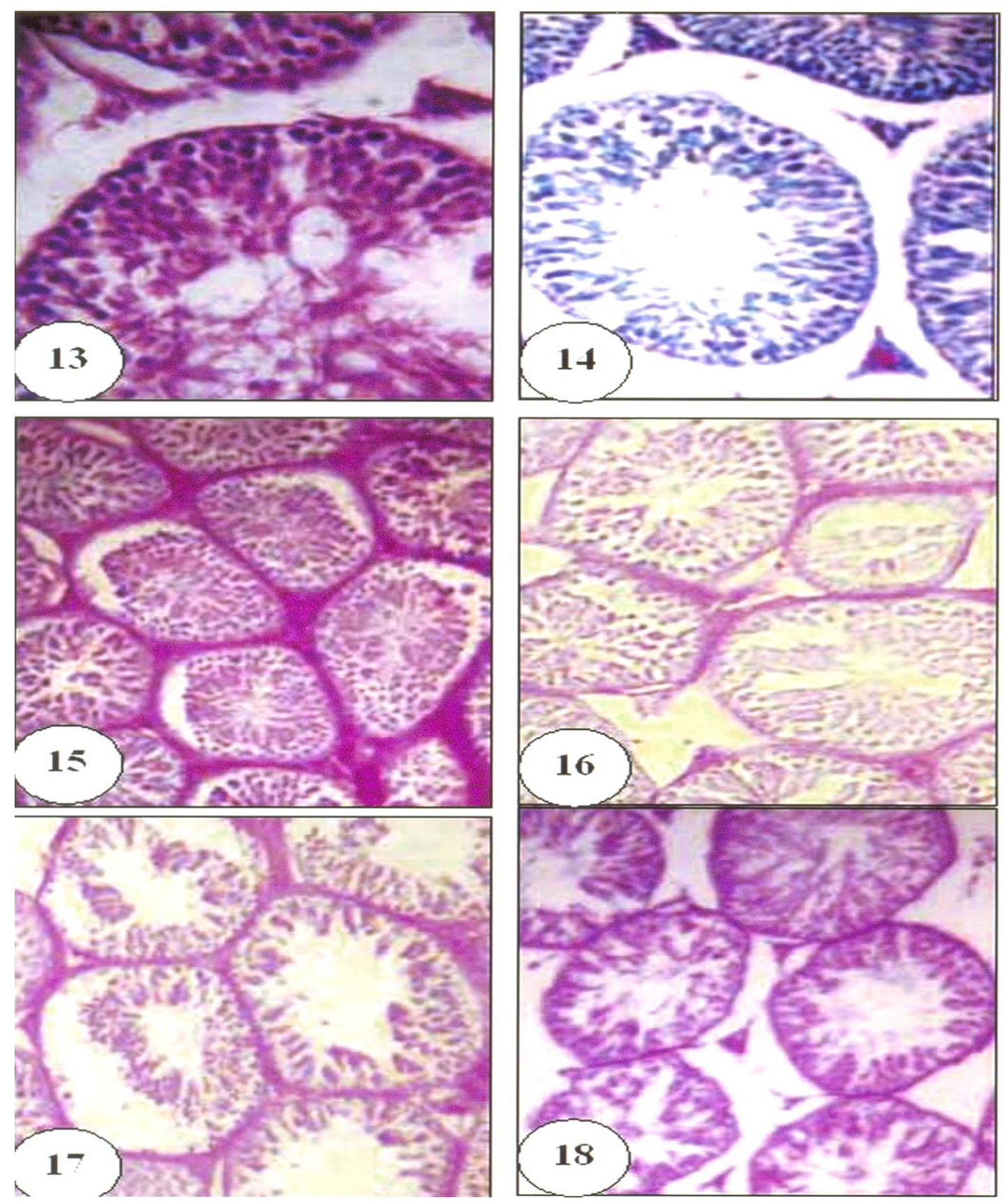

Fig. (13): Transverse section of the testis of rat treated with septilin and irradiated with 6 Gy showing slight ameliorative effects. (H/E stain X 400).

Fig. (14): Transverse section of the testis of rat treated with septilin and irradiated with $6 \mathrm{~Gy}$ showing less collagen fibres. (Masson's trichrome X 100).

Fig. (15): Transverse section of control rat testis showing the normal polysaccharides content. (PAS stain X 100).

Fig. (16): Transverse section of rat irradiated with 3 Gy showing decrease in the polysaccharides content. (PAS stain X 100).

Fig. (17): Transverse section of rat irradiated with 6 Gy showing severe decrease in the polysaccharides content. (PAS stain X 200).

Fig. (18): Transverse section of the testis of rat treated with septilin and irradiated with 6 Gy showing slight decrease in the polysaccharides content. (PAS stain X 200). 


\section{Discussion}

In the present study, histopathological changes of the testes were assessed after one week of gamma-irradiation with or without pretreatment of septilin in male albino rats. In this study, severe atrophy of the seminiferous tubules with necrotic cells, pyknotic nuclei and complete loss of germ cells were observed in most seminiferous tubules in the rats irradiated with 3 or 6 Gy of gamma-radiation. However, other tubules showed normal spermatogenesis with a few degenerating germ cells. The dose and time response of rat testis to gamma-irradiation was studied with use of single doses from 2.5 Gy to $6.0 \mathrm{~Gy}$.

Germ cells were initially depleted as a result of killing the radiosensitive differentiating spermatogonia (Kangasniemi et al., 1996). Spermatogonial depletion due to testicular toxicants and seminiferous tubule atrophy by impairment of spermatogenesis was documented (Son et al., 1999). In irradiated mice, ( 8 Gy) the germinal epithelium was highly disorganized with shrinkage of tubules, absence of sperm and spermatids shrinkage in their size of sertoli cells and Leydig cells (Kumar et al., 2006). However, in the present study necrosis appeared at earlier stages even in the spermatogonia. Otherwise, Ghanem et al. (1995) showed that the occurrence of many pathological changes in primary and secondary spermatocytes could be due to the fact that those cells were derived from injured spermatogonia. In agreement with the present study, gamma irradiation resulted in death of the spermatogenic cells and this death was more obvious in the spermatogonia in the testes of rats (PinonLataillade et al., 1991).

Moreover, radiotherapy is widely used for cancer therapy; although the treatments could be successful, patients often complain of azoospermia or infertility (Taksey et al., 2003). Radiation doses as low as 0.1-0.2 Gy exerted detectable effects on spermatogenesis in adult men (Centola et al., 1994) and high doses over 4 Gy caused in permanent azoospermia (Relander et al., 2000). The vacuolation observed in the spermatogenic cells as a result of gamma radiation is attributed in part to a progressive hypoxia and partly to fatty accumulation as a result of cell degeneration (Bhatavdekar et al., 1977). In respect to giant cells observed in the testis of gamma-irradiated animals, Labib (1995) suggested that the multinucleated giant cells were derived from the fusion of two or three primary spermatocytes. The present data showed that the interstitial spaces in the testis of irradiated animals appeared larger than those in the control animals and most Leyding cells became degenerated. Comparable observations were reported by Labib (1995). Whoever, the exposure of the mammalian testis to ionizing radiation at even low dose might cause significant disturbance in the spermatogenesis process and differentiation of the spermatozoa (Khattab et al., 1995). The present data showed significant reduction in the number of spermatogonia, primary spermatocytes, secondary spermatocytes and spermatids due to gamma irradiation; this decrease was more pronounced with the high dose than the low one. In agreement with these data, significant decrease in the number of spermatogonia, primary spermatocytes, secondary spermatocytes and spermatids in irradiated mice was noticed (Kumar et al., 2006).

According to Filippi and Mela (1958) gradual decrease in the carbohydrate content of the spermatogenic cells, especially in the spermatids which are the main site of carbohydrates in the testis, as a results of exposure to different xenobiotics. Harman (1983) suggested that the accumulated free radicals in the cells attack. The DNA and lead to cross-linkages with the molecules and these result in reduction of their biological activity. The present study showed that gamma irradiation induced significant reduction in the polysaccharides content and significant increase in the collagen fibres in the testes of rats.

Harmful effects of ionizing radiation in mammals are known for a long time and attempts have been made to find out suitable protective agents against these 
effects. Radioprotective agents are defined as compounds that help to diminish the biological effects of ionizing radiation when administered before exposure to radiation (Satoh et al., 2003). Various other experimental approaches, aimed at preventing radiation-induced quantitative damage to the gonads, have been explored (Jegou et al., 1991; Lee et al., 1998 and Landauer et al., 2005). The present study showed that spetilin has strong protective effects against gamma-radiation induced testicatular histological alterations in rats. Septilin in oral daily dose of $100 \mathrm{mg} / \mathrm{kg} \mathrm{b}$. wt. for one week prior to gamma-irradiation could attenuate the histological lesions observed under the effect of gammairradiation especially with the low dose of this radiation. Similarly, in mice treated with extract of Adhatoda vasica and then exposed to radiation dose, the ameliorative effect determined by intact germinal epithelium, no pyknosis, necrosis, karyolysis present, less cytoplasmic vacuolization and number of germ cells increased by day 30 (Kumar et al., 2006).

\section{Conclusion}

The present study proved that septilin exerts a strong effect against whole body gamma irradiation-induced testicular histopathological changes, where it efficiently ameliorated the deleterious influences of ionizing radiation when administered preexposure. The results have implication for the potential use of septilin as a radioprotector.

\section{References}

1. Bhatavdekar J M, Aravinda B K. and Shah V C. (1977) Effect of low dose Xirradiation on nucleic acids and protein content of guinea pig, rat and mouse tissue. Ind. J. Exp. Biol., 15: 908-912.

2. Centola G M, Keller J W, Henzler $M$. and Rubin P. (1994) Effect of low-dose testicular irradiation on sperm count and fertility in patients with testicular seminoma. J. Androl., 15: 608-613.

3. Dobson R L. and Felton J S. (1983): Female germ cell loss from radiation and chemical exposures. Am. J. Ind. Med., 4:175-190.
4. Filippi B. and Mela V. (1958) Malformation congenitales et antibiotique. Arch. Fr. Pediat., 15: 565.

5. Geraci J P, Mariano M S. and Jackson K L. (1992) Radiation hepatology of the rat: Microvascular fibrosis and enhancement of liver dysfunction by diet and drugs. Radiat. Res., 129: 322-332.

6. Ghanem N F, Attia S I, Risk A M. and Shwaireb M H. (1995) Effect of antithyroid drug cabimazole on the fertility and testicular structure of mice. J. Egypt. Ger. Soc. Zool., 18(C): 1-12.

7. Georgieva T S, Yablanskii P, Georgiev D, Yakov M. and Oblakova M. (2005) Reciprocal translocation and reproductive capacity in rabbits following external gamma irradiation. Bulgarian J. Vet. Med., 8(4): 227-232.

8. Jagetia G C. and Baliga M S. (2004) Polyherbal extract of septilin protects mice against whole body lethal dose of gamma radiation. Phytother. Res., 18(8): 619-623.

9. Jagetia G C, Venkatesh $P$. and Baliga $M$ S. (2004) Evaluation of the radioprote-ctive effect of A. vasica leaf (Avasicagle marmelos) extract in mice. Int. J. Radiat. Biol., 80: 281-90.

10. Jegou B, Callet J. and Baucho F. (1991) Protective effect of medroxyproges-terone acetate plus testosterone against radiationinduced damage to the reproduc-tive function of male rats and their offspr-ing. Proc. Natl. Acad. Sci. USA, 88: 8710-8714.

11. Harman D. (1983) Free radical theory of aging consequences of mitochondrial aging. Age, 6: 86-94.

12. Kangasniemi M, Veromaa T I, Kulmala J, Kaipia A, Parvinen M. and Toppari J. (1990) DNA-flow cytom-etry of defined stages of rat seminiferous epithelium: effects of 3 Gy of high-energy Xirradiation. J. Androl., 11: 312-317.

13. Kangasniemi M, Huhtaniemi I. and Meistrich M. (1996) Failure of permatogenesis to Recover Despite the Presence of A Spermatogonia in the Irradiated LBNF1 Rat. Biol. Repr., 54: 1200-1208.

14. Khattab F, Roushdy H. and El-Dawy $H$. (1995) Effect of ionizing radiation on sperm of mice. Egypt. J. Rad. Sci. Applic., 8(2): 141-148.

15. Kumar P V, Kuttan G. and Luttan R. (1993) Immunomodulatory activity of septilin. Probe; 33: 1-5.

16. Kumar M, Samarth R, Kumar M, Senthamil R, Begraj S. and Kumar A. (2006) Protective effect of Adhatoda vascia Nees against radiation-induced damage at 
cellular, biochemical and chromosomal levels in Swiss albino mice. Compl. and Altern. Med., 5: 1- 8.

17. Labib M M. (1995) Histological changes and withdrawal in gonads of young rats response to the administration of heroin. J. Union Arab Biol., 3(A) : 135-157.

18. Lamartiniere C A, Cotroneo M S, Fritz W A, Wang J, Mentor-Marcel R. and Elgavish A. (2002) Genistein chemoprevention: timing and mechanisms of action in murine mammary and prostate. J. Nutr., 132: 552S-558S.

19. Landauer M R, Srinivasan V, Grace $M$ B, Chang C M, Parekh V, Clarke T K. and Jackson W.E. (2005) Prevention of Gamma Radiation-Induced Mortality in Mice by the Isoflavone Genistein. NATO $R T G-099$.

20. Lee Y, Change W, Kimi J K. and Yoon Y. (1998) Effects of gamma radiation on ovarian follicles. Arh. Hig. Rada. Toksikol., 49 (2): 147-153.

21. Matalka K Z, Barth R F, Bailey M Q, Koestner A D. and Hopewell J W. (1994) Radiation effect of boron neutron capture therapy on brain, skin and eye of rats. Int. J. Radiat. Oncol. Biol. Phys., 28: 1089- 1097.

22. Mc Manus, J.P.A. (1946) Histological demonstration of mucin after periodic acid. Nature (London), 158: 202.

23. Mian T A, Suzuki N, Glenn H J, Haynie T P. and Meistrich M L. (1977) Radiation damage to mouse testis cells from $\left({ }^{99 \mathrm{~m}} \mathrm{Tc}\right)$ pertechnetate. J. Nucl. Med., 18: 11161122.

24. Meistrich M L. (1993) Effects of chemotherapy and radiotherapy on spermatogenesis. European Urology, 23: 136_142.

25. Pearse A G. (1972) Histochemistry, theoretical and applied. $3^{\text {rd }}$ ed. Vol. 11, Little, Brownand com. Boston.

26. Pinon-Lataillade G, Viguier-Martinez $\mathbf{M}$ C, Touzalin A M, Maas J. and Jegou B. (1991) Effect of an acute exposure of rat testes to gamma rays on germ cells and on Sertoli and Leydig cell functions. Reprod. Nutr. Dev., 31(6): 617-629.

27. Rades D, Fehlauer F, Bajrovic A, Mahlmann B, Richter E. and Alberti W. (2004) Serious adverse effects of amifostine during radiotherapy in head and neck cancer patients. Radiother Oncol., 70: 261-264.

28. Relander T, Cavallin-Stahl E. Garwicz S, Olsson A M. and Willen M. (2000) Gonadal and sexual function in men treated for childhood cancer. Med. Pediatr. Oncol., 35: 52-63.

29. Rom D G. (1984) The anti-infective and anti bacterial efficacy of septilin. Probe, 23: 84-87.

30. Rowley M J, Leach D R, Warner G A. and Heller C G. (1974) Effect of graded doses of ionizing radiation on the human testis. Radiat. Res., 59: 665-678.

31. Sharma S B. and Ray S. (1997) Effect of herbal preparation on immune response of immunosuppressed mice. Ind. J. Physiol. Pharmacol., 41: 293-296.

32. Son H Y, Kim Y B, Kang B H, Cho S W, Ha C S. and Roh J K. (1999) Effect of 2bromopropane on spermatoge-nesis in the Spargue-Dawley rat. Reprod. Toxicol., 13: 179-187.

33. Satoh H, Nishikawa K, Suzuki K, Asano R, Virgona N, Ichikawa T, Hagiwara K. and Yano T. (2003) Genistein, a soy isoflavone, enhances necrotic-like cell death in a breast cancer cell treated with a chemotherapeuticagent, Res. Commun. Mol. Pathol. Pharmacol., 113-114: 149-158.

34. Taksey J, Bissada N K. and Chaudhary U B. (2003) Fertility after chemotherapy for testicular cancer. Arch. Androl., 49: 389-395.

35. Uma Devi P, Ganasoundari A, Vrinda B, Srinivasan K K. and Unnikrishnan M K. (2000) Radiation protection by ocimum flavonoids orientin and vicenin: mechanism of action. Radiat. Res., 154: 455-60.

36. Weiss J F, Landauer M R. (2003) Protection against ionizing radiation by antioxidant nutrients and phytochemicals, Toxicology. 189: 1-20.

37. Yang W, Barth R F, Rotaru J H, Boesel C P, Wilkie D A, Bresnahan J, Hadjiconstantinou M, Goettl V M, Joel D D. and Nawrocky M M. (2000) Boron neutron capture therapy of brain tumors: functional and neuropathhological effects of blood brain barrier disruption and intracarotid injection of sodium borocaptate and boronopheny-lalanine. J. Neurooncol., 48: 179-190. 


\section{الاور الوقائى للسيتلين ضد الأضرار التى تعلثها أشعة جاما فى خصية}

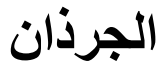

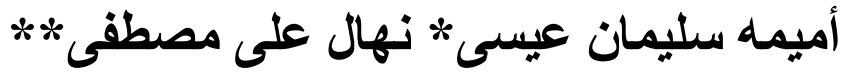

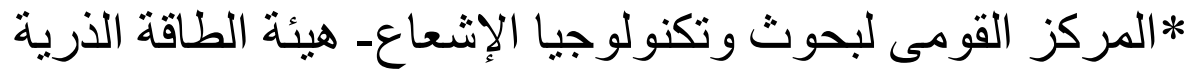

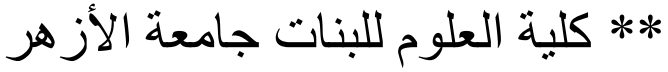

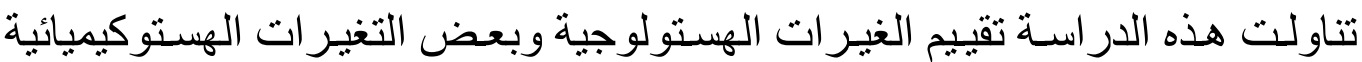

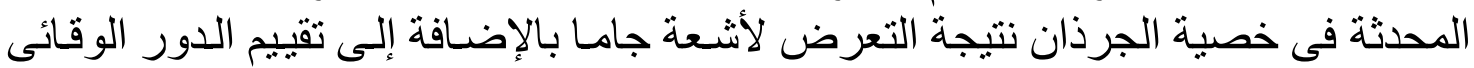

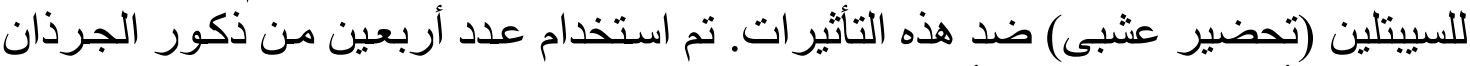

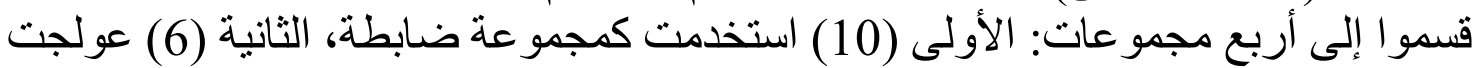

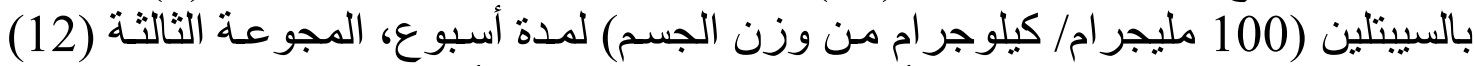

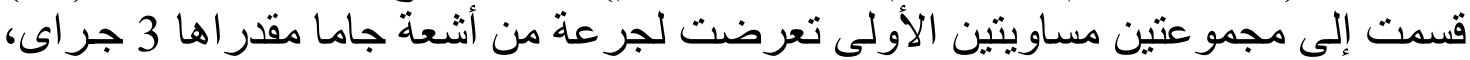

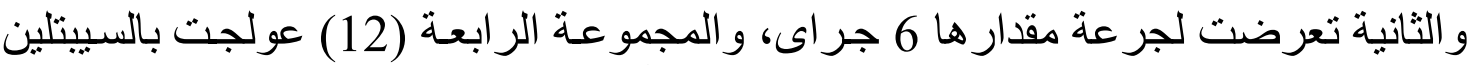

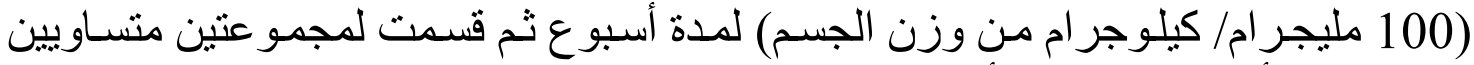

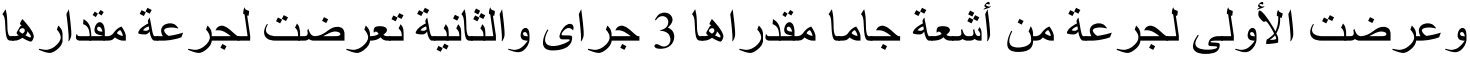

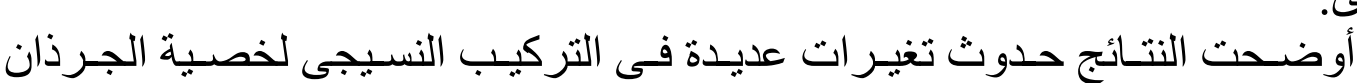
6

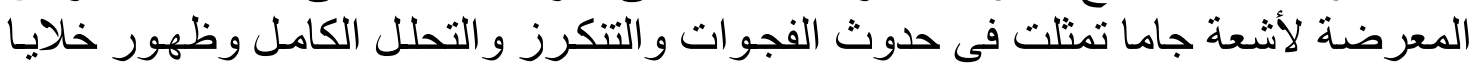

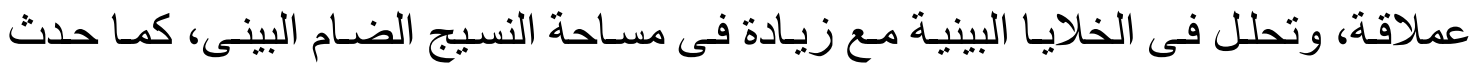

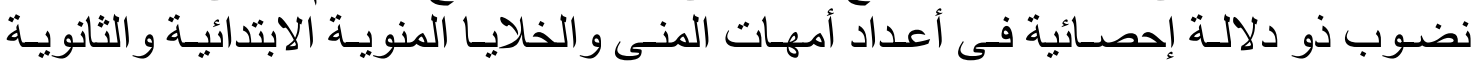

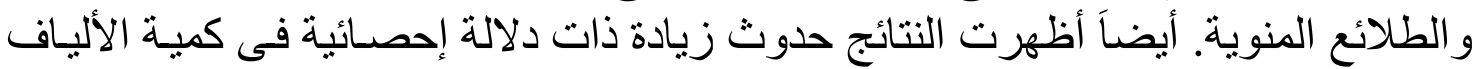

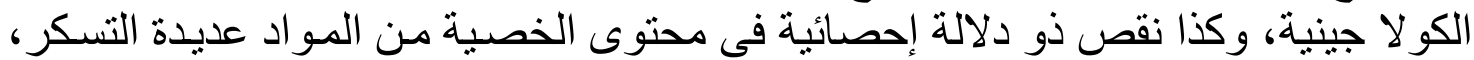

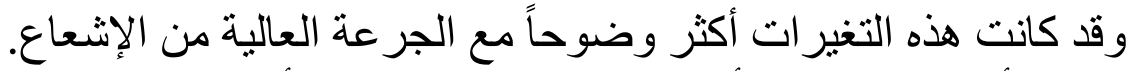

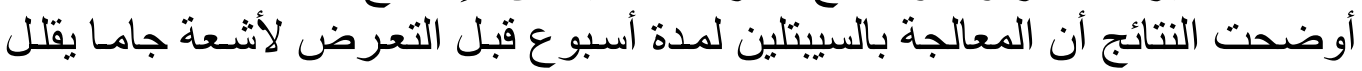

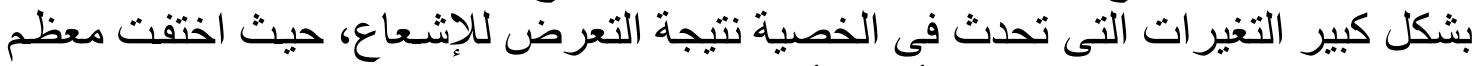

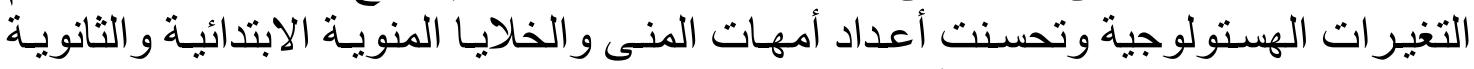

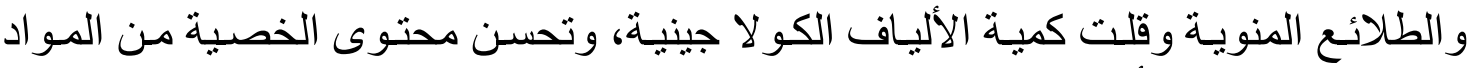

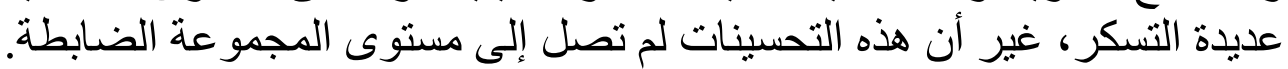

